\title{
Correlation between audiometric data and the 35delG mutation in ten patients
}

\author{
Vânia Belintani Piatto ', Otávio Augusto Vasques \\ Moreira ', Magali Aparecida Orate Menezes da \\ Silva ${ }^{3}$, José Victor Maniglia ${ }^{4}$, Márcio Coimbra \\ Pereira ${ }^{5}$, Edi Lúcia Sartorato ${ }^{6}$
}

Keywords: molecular analysis, audiometry, hearing loss, 35delg mutation.

\section{Summary}

\begin{abstract}
$\mathrm{M}$ the connexin 26 gene seem to be extremely common in non-syndromic hereditary deafness genesis, especially the $35 \mathrm{delG}$, but there are still only a few studies that describe the audiometric characteristics of patients with these mutations. Aim: to analyze the audiometric characteristics of patients with mutations in the connexin 26 gene in order to outline genotype-phenotype correlation. Materials and Methods: Tonal audiometries of 33 index cases of non-syndromic sensorineural hearing loss were evaluated and eight affected relatives. Specific molecular tests were carried out to analyze mutations in the connexin 26 gene. Experiment Design: Retrospective, cross-sectional study. Results: A $27.3 \%$ prevalence of mutation 35delG was found in the index cases and $12.5 \%$ among the relatives affected. In relation to hearing loss degree, $41.5 \%$ of the patients were found with profound hearing loss, 39\% with severe HL and $19.5 \%$ with moderate HL with homozygote and heterozygote patients for the $35 \mathrm{delG}$ predominating in the severe-moderate hearing losses. Conclusion: Our results suggest that the audiometric data associated with the molecular diagnose of hearing loss helped us to outline a genotype-phenotype correlation in ten patients with 35 delG mutation. However, it is still necessary to run multicentric studies to verify the real phenotypic expression in the Brazilian population, as far as the $35 \mathrm{delG}$ mutation is concerned.
\end{abstract}

${ }^{1} \mathrm{PhD}$, Adjunct Professor - Department of Otorhinolaryngology / Head and Neck Surgery - FAMERP. 25 th Year Medical Student - FAMERP.

${ }^{3}$ M.Sc. Head of the Speech and Hearing Therapy Division - Department of Otorhinolaryngology / Head and Neck Surgery - FAMERP

${ }^{4}$ Associate Professor - Head of the Department of Otorhinolaryngology / Head and Neck Surgery - FAMERP. ${ }^{5}$ M.Sc. Department of Otorhinolaryngology / Head and Neck Surgery - FAMERP.

${ }^{2} \mathrm{PhD}$. Head of the Center for Molecular Biology and Genetic Engineering - CBMEG-UNICAMP. Faculdade de Medicina de São José do Rio Preto, SP - FAMERP. BIC-FAMERP (Bolsa de Iniciação Científica - FAMERP). 


\section{INTRODUCTION}

It is well known that in developed countries one in 750 births is likely to produce a child with sensorineural hearing impairment and it is estimated that one in 1000 children is affected by severe deafness at birth or by the end of the prelingual period ${ }^{1}$. Approximately $60 \%$ of all causes of prelingual deafness can be attributed to genetic factors. Therefore, the genetic etiology is becoming increasingly relevant in cases of hearing impairment and/or deafness. The remaining $40 \%$ are distributed over a vast variety of etiologies ${ }^{2}$. There are three identifiable kinds of inheritance pattern for the inherited deafness: autosomal recessive, autosomal dominant, and X-linked. From 75\% to $85 \%$ of cases of non-syndromic prelingual deafness are manifested as autosomal recessive forms. Autosomal dominant forms account for about $15 \%$ to $25 \%$ of cases, and the remaining $1 \%$ to $3 \%$ are of $\mathrm{X}$-linked Mendelian inheritance. There are also descriptions of forms which are inherited exclusively from the mother, corresponding to mitochondrial inheritance, associated or not with autosomal dominant inheritance ${ }^{2,3}$.

In terms of phenotype, the autosomal recessive for$\mathrm{ms}$ are more severe, being responsible for almost all forms of congenital deafness. These, in turn, are caused in great part by cochlear defects, leading to sensorineural hearing impairment. The autosomal dominant forms seem to contribute more to cases of postlingual deafness, which are usually progressive, and the impairment is, in most cases, conductive or mixed (conductive and sensorineural) ${ }^{4,5}$.

Mutations in the conexin 26 or GJB2 - Gap Junction Protein Beta 2 gene, located on the long arm of chromosome 13 (13q11-12), appear to be extremely common in the genesis of inherited non-syndromic deafness, and account for $34 \%$ to $50 \%$ of autosomal recessive sensorineural deafness (DFNB1) and for $10 \%$ to $37 \%$ of sporadic cases ${ }^{6-10}$.

Deletion of a guanine out of a sequence of six guanines going from position 30 to position 35 in the conexin 26 (GJB2) gene is the mutation that occurs in 60\% to 80\% of cases. This nucleotide deletion can occur at position 35 (35delG) or at position 30 (30delG) of the gene, but the deletion at position 35 (35delG), genetically related to chromosome 13 , is the more frequent one, varying between approximately $50 \%$ to $85 \%$ of the non-syndromic deafness cases in patients from Italy, Spain, and Israel ${ }^{7,11-}$

${ }^{13}$. In a study with Brazilian patients14, mutations in gene GJB2 were found in 22\% of families tested with at least one patient with hearing loss, and in $11.5 \%$ of cases in which an environmental etiology was not completely ruled out. In the cases in which this mutation in conexin 26 gene occurs, the gene product, a protein named conexin, no longer exerts its functions correctly, while the cochlea is structurally normal ${ }^{15}$.

Even though the GJB2 gene is of great importance in the etiology of non-syndromic sensorineural impairment, there are so far very few studies describing the audiometric characteristics of patients with mutations in the GJB2 gene associated with hearing loss, especially in Brazil. According to these studies, in patients who are homozygous for mutations in the GJB2 gene and mainly in those who are homozygous for $35 \mathrm{delG}$, the hearing loss is characterized for being prelingual, affecting all frequencies, being nonprogressive, varying in degree from moderate to deep, even among impaired siblings of the same family, and not being associated with vestibular alterations and radiological abnormalities of the inner ear ${ }^{16,17}$. The present study had the objective of analyzing the audiometric characteristics of patients with mutations in the conexin 26 gene, in order to outline a genotype-phenotype correlation.

\section{PATIENTS AND METHOD}

During the period from March through June, 2000, a cross-section study was carried out, in which 33 index cases ( 23 male and 10 female) with non-syndromic sensorineural hearing impairment were investigated. They aged between 3 and 37 years, were randomly selected at the Ear-Nose-Throat Outpatient Clinic. Of these index cases, eight relatives were evaluated ( 4 male and 4 female), aged 11 to 45 years, who also presented non-syndromic sensorineural hearing impairment. Hence, we evaluated 33 families with at least one member with hearing loss, totaling 41 impaired individuals. This study was approved by the Research Ethics Committee, Protocol No. 4429/2000. The complete history of each patient was obtained to investigate age at onset of the hearing impairment, presence of other cases in the family, and to exclude the possibility of environmental causes such as, maternal-fetal infections, perinatal complications, meningitis, use of ototoxic drugs, acoustic trauma. Physical, otorhinolaryngological and systemic examinations, as well as complementary tests, were carried out to exclude signs suggesting syndromic forms of hearing loss (especially craniofacial dysmorphism, skin disorders, anomalies of branchial, cardiac or thyroidal origin, vision disorders, etc.). Moreover, patients were submitted to ophthalmologic evaluation (including fundoscopy), vestibular tests and computerized tomography of the temporal bone. Thus, a complete clinical evaluation was performed to exclude patients with hearing loss caused by environmental factors, congenital malformations of the inner ear or genetic syndromes. The patients were audiologically tested by pure-tone audiometry, performed at the Speech Therapy Outpatient Clinic, and those with non-syndromic sensorineural hearing impairment classified as mild (25-40 dB), moderate (41-60 dB), severe (61-80 $\mathrm{dB})$ or profound $(>81 \mathrm{~dB})$ were included ${ }^{18}$.

Molecular analysis was carried out at the Molecular Biology Center, after DNA extraction from whole blood, done at the Genetics and Molecular Biology Research Unit, 
using a genomic DNA extraction kit (GFXTM Genomic Blood DNA Purification Kit, Amersham Pharmacia Biotech Inc.), according to the manufacturer protocol. To detect the 35 delG mutation, the technique used was allele-specific polymerase chain reaction (AS-PCR) with specific primers8. Primers named control A (direct) and B (reverse) were also synthesized, for co-amplification of the GJB2 gene with a segment of the amelogenin gene homologous to the X-Y chromosome, thus being used as internal amplification controls19. Additionally, the PCR technique was used to detect the Delta (GJB6 - D13S1830) mutation, with specific primers20, in heterozygous samples and in those who did not present the $35 \mathrm{delG}$ mutation. The AS-PCR and PCR products were analyzed by electrophoresis on $1.5 \%$ agarose gel in TBE $1 \mathrm{X}$ buffer, containing ethidium bromide, at a concentration of $0.5 \mathrm{mg} / \mathrm{mL}$, submitted to ultraviolet light to confirm that the reaction was successful, and the gel was photographed. The samples which did not present the mutations under study on both alleles, or heterozygous samples, were submitted to automated sequencing.

Two pairs of primers were synthesized ${ }^{21}$ and amplification of the GJB2 gene in two fragments was obtained by the PCR reaction prior to sequencing. The amplified fragments were purified using the Wizard SV Gel and PCR Clean-UP System Kit (PROMEGA), and the sequencing reactions were run in both directions in an ABI PRISMTM 377 automated sequencer (Perkin Elmer) using the BigDyeTM Terminator Cycle Sequencing Kit V2.0 Ready Reaction (ABI PRISM/PE Biosystems). The sequences obtained were analyzed and compared with the normal sequence, using the Gene Runner V3.05 program to align the nucleotide sequences and the Chromas V1.45 program to edit the electropherograms.

The present retrospective study was submitted to and approved by the Research Ethics Committee, Protocol No. 2813/2004, in order to review the molecular and audiometric data of patients.

Percentages with their respective standard deviations were calculated, and the results are expressed in $\%(\mathrm{SD} \%)$.

\section{RESULTS}

Table 1 presents the overall genotype results obtained after molecular analysis performed in the 33 index cases and 8 affected relatives. The clinical and audiometric data concerning the index cases, such as gender, age, time of onset and degree of hearing loss, and familial recurrence, are shown in Chart 1.

Therefore, we found a prevalence of $27.3 \%$ $(\mathrm{SD} \%=7.7)$ for the $35 \mathrm{delG}$ mutation in the index cases analyzed $(9 / 33)$, of $21.2 \%(\mathrm{SD} \%=5.03)$ of the alleles $(14 / 66)$ with the $35 \mathrm{delG}$ mutation, and of $12.5 \%(\mathrm{SD} \%=11.69)$ in the affected relatives. For each mutation, V37I and Delta (GJB6$\mathrm{D} 13 \mathrm{S1830})$, a $3 \%$ prevalence (SD\%=2.96) was found.
Table 1. Distribution of index cases (n) and affected relatives (n) in relation to the genotypes found by molecular analysis of the GJB2 gene and the Delta (GJB6 - D13S1830) mutation.

\begin{tabular}{ccccc}
\hline Genotype & \multicolumn{2}{c}{$\begin{array}{l}\text { Index cases } \mathrm{n} \\
(33) \%\end{array}$} & $\begin{array}{c}\text { Affected relatives } \\
\mathrm{n}(8) \%\end{array}$ \\
\hline Homozygous 35delG & 5 & 15.2 & 0 & 0 \\
$\begin{array}{c}\text { Heterozygous 35delG } \\
\text { Composite hetero- }\end{array}$ & 2 & 6.1 & 0 & 0 \\
$\begin{array}{c}\text { zygous 35delG/V37I } \\
\text { Composite hete- }\end{array}$ & 1 & 3.0 & 0 & 0 \\
$\begin{array}{c}\text { rozygous 35delG/ } \\
\text { D(GJB6-D13S1830) }\end{array}$ & 1 & 3.0 & 1 & 12.5 \\
\hline Total & 9 & 27.3 & 1 & 12.5 \\
\hline No mutation & 24 & 72.7 & 7 & 87.5 \\
\hline Total & 33 & 100 & 8 & 100 \\
\hline
\end{tabular}

The audiometric tests performed in patients with hearing impairment $(n=41)$ showed the following results with regard to degree of loss: profound - 17 patients $(41.5 \%, \mathrm{SD} \%=7.69)$; severe -16 patients $(39.0 \%, \mathrm{SD} \%=7.61)$ and moderate -8 patients $(19.5 \%, \mathrm{SD} \%=6.18)$. Of the five patients who were homozygous for $35 \mathrm{del} G$, one presented a profound degree $(2.43 \%, \mathrm{SD} \%=2.40)$, three presented a severe degree $(7.31 \%, \mathrm{SD} \%=4.06)$, and one patient presented a moderate degree of hearing loss $(2.43 \%, \mathrm{SD} \%=2.40)$. Of the two patients who were heterozygous for $35 \mathrm{delG}$, one $(2.43 \%, \mathrm{SD} \%=2.40)$ presented a severe and the other $(2.43 \%, S D \%=2.40)$ a moderate degree of hearing loss. The patient who was a 35delG/V37I composite heterozygote $(2.43 \%, \mathrm{SD} \%=2.40)$ and the two 35delG/Delta (GJB6D13S1830) composite heterozygotes $(4.87 \%, \mathrm{SD} \%=3.36)$ presented a severe degree of hearing loss. The predominant audiometric frequencies were 4000 to $8000 \mathrm{Hertz}$ $(\mathrm{Hz})$. All patients with the $35 \mathrm{delG}$ mutation presented hearing loss with prelingual onset.

The phenotype/genotype correlation of the index cases and affected relatives, with the diagnosed mutation, is represented in Chart 2.

\section{DISCUSSION}

In the present study, we found a $27.3 \%$ prevalence of the 35delG mutation in the index cases analyzed, $21.2 \%$ of alleles with the mutation, and $12.5 \%$ in the affected relatives. A prevalence of $3 \%$ was also assessed for each one of the mutations V37I and Delta (GJB6-D13S1830), found in the study. These results are concordant with previous studies reported in the literature, conducted in several populations ${ }^{22-26}$. The relative contribution of the $35 \mathrm{delG}$ mutation to the non-syndromic hearing loss in these populations varied from 0\% (Oman, Korea, Japan) to 70\% (Italy, Spain, Greece), demonstrating the genetic heterogeneity among the different countries, even though some of these 
Chart 1. Clinical and audiometric data of the 33 index cases of the study and 8 affected relatives $(n=41)$ who were submitted to molecular analysis of the GJB2 gene and the Delta (GJB6-D13S1830) mutation.

\begin{tabular}{|c|c|c|c|c|c|c|c|}
\hline $\begin{array}{l}\text { Index cases } \\
\text { (IC) }\end{array}$ & Sex & $\begin{array}{c}\text { Age } \\
\text { (years) }\end{array}$ & $\begin{array}{c}\text { Onset of } \\
\mathrm{HL}\end{array}$ & $\begin{array}{c}\text { Degree of } \\
\mathrm{HL}\end{array}$ & $\begin{array}{l}\text { Familial Recur- } \\
\text { rence }\end{array}$ & $\begin{array}{c}\text { Age } \\
\text { (years) }\end{array}$ & $\begin{array}{c}\text { Degree of } \\
\mathrm{HL}\end{array}$ \\
\hline 1 & $\mathrm{M}$ & 15 & Prelingual & Severe & & & \\
\hline 3 & M & 9 & Prelingual & Severe & & & \\
\hline 4 & $\mathrm{~F}$ & 28 & Postlingual & Profund & & & \\
\hline 7 & M & 4 & Prelingual & Profund & & & \\
\hline 8 & $\mathrm{~F}$ & 10 & Postlingual & Severe & & & \\
\hline 9 & M & 7 & Prelingual & Profund & & & \\
\hline 10 & M & 3 & Prelingual & Severe & & & \\
\hline 14 & M & 9 & Prelingual & Profund & & & \\
\hline 15 & M & 6 & Prelingual & Severe & & & \\
\hline 16 & M & 5 & Prelingual & Profund & & & \\
\hline 17 & $\mathrm{~F}$ & 33 & Prelingual & Severe & $\begin{array}{c}\text { sister } \mathrm{Cl} 18 \\
\text { brotherCl19 } \\
\text { brotherCl20 }\end{array}$ & $\begin{array}{l}28 \\
37 \\
19\end{array}$ & $\begin{array}{c}\text { Moderate } \\
\text { Profund } \\
\text { Profund }\end{array}$ \\
\hline 21 & M & 37 & Postlingual & Profund & & & \\
\hline 22 & M & 8 & Prelingual & Severe & & & \\
\hline 23 & M & 15 & Prelingual & Severe & & & \\
\hline 32 & M & 17 & Prelingual & Profund & sister Cl33 & 26 & Profund \\
\hline 34 & $\mathrm{~F}$ & 14 & Prelingual & Severe & brotherCl35 & 35 & Severe \\
\hline 36 & M & 32 & Prelingual & Profund & & & \\
\hline 37 & M & 7 & Prelingual & Profund & mãe $\mathrm{Cl} 38$ & 45 & Moderate \\
\hline 39 & M & 15 & Prelingual & Moderate & & & \\
\hline 40 & M & 6 & Prelingual & Severe & & & \\
\hline 41 & $\mathrm{M}$ & 16 & Prelingual & Moderate & & & \\
\hline
\end{tabular}

(IC)- Index cases; (M)- Male; (F)- Female; (HL)- Hearing loss 
Chart 2. Phenotype and genotype of the index cases and affected relatives with mutations in the GJB2 gene and with the Delta (GJB6D13S1830) mutation

\begin{tabular}{|c|c|c|c|c|c|}
\hline $\begin{array}{l}\text { Index cases } \\
\text { (IC) }\end{array}$ & $\begin{array}{c}\text { Onset } \\
\mathrm{HL}\end{array}$ & Degree & $\begin{array}{c}\text { Mutation } \\
\text { Allele 1/Allele } 2\end{array}$ & $\begin{array}{c}\text { Familial Recurrence } \\
\text { with Mutation }\end{array}$ & Degree \\
\hline 1 & Prelingual & Severe & 35delG/V37I & ----- & ----- \\
\hline 10 & Prelingual & Severe & 35delG/35delG & ----- & ----- \\
\hline 15 & Prelingual & Severe & 35delG/35delG & ---- & ---- \\
\hline 23 & Prelingual & Severe & 35delG/Normal & ----- & ---- \\
\hline 24 & Prelingual & Severe & 35delG/35delG & ----- & ----- \\
\hline 25 & Prelingual & Profundo & 35delG/35delG & ----- & ----- \\
\hline 26 & Prelingual & Moderate & 35delG/35delG & ---- & ----- \\
\hline 34 & Prelingual & Severe & $\begin{array}{c}\text { 35delG/Delta(GJB6- } \\
\text { D13S1830) }\end{array}$ & $\begin{array}{c}\text { brother Cl35 } \\
\text { 35delG/Delta(GJB6- } \\
\text { D13S1830) }\end{array}$ & Severe \\
\hline 39 & Prelingual & Moderate & 35delG/Normal & ---- & ----- \\
\hline
\end{tabular}

IC - Index cases; HL - Hearing loss

studies were based on a small number of patients, besides the differences in the impairment investigation criteria and the mutation screening methods $\mathrm{s}^{23,27-30}$.

Recent studies found a 342 thousand base-pair ( 342 $\mathrm{Kb})$ deletion close to the GJB6 [D(GJB6 - D13S1830)] gene, suggesting that this mutation could cause non-syndromic recessive hearing loss, either by a homozygous deletion or by digenic penetrance of the deletion in the GJB6 gene, associated with a trans mutation in the GJB2 gene in the heterozygous cases ${ }^{24}$. Most genetic cases of hearing impairment result from mutations in a single gene, but an increasing number of cases with two involved genes have been identified31. A multicenter study conducted in nine countries demonstrated that the Delta (GJB6-D13S1830) mutation is more frequent in France, Spain, Israel, the United Kingdom and Brazil, varying from 5.9\% to 9.7\% of all studied alleles of patients with DFNB1, and being present in about $50 \%$ of heterozygous patients in Spain $^{32}$. In the present study, a $3 \%$ prevalence of the deletion in the GJB6 gene in heterozygosis with the 35delG mutation was found, which is in agreement with data from the literature ${ }^{24,32}$.

In Brazil, a study conducted in newborns from the region of Sao Jose do Rio Preto, SP ${ }^{33}$, found a 2.24\% (1:44.6) prevalence of heterozygotes for the $35 \mathrm{del} G$ mutation, and another newborn screening, performed in the region of Campinas, $\mathrm{SP}^{34}$, found a $0.97 \%$ (1:103) prevalence of heterozygotes. In another study, performed in patients with hearing loss, mutations in the GJB2 gene were found in $33.5 \%$ of cases, and only the $35 \mathrm{delG}$ mutation was identified in $84.2 \%$ of mutant alleles ${ }^{14}$. The methodology used in the current study, AS-PCR and automated sequencing, was similar to the three above mentioned researches, but a variation was found in the frequency of the alleles with the 35delG mutation. This finding can be explained by differences in the sample or maybe by the highly heterogeneous ethnic composition of the Brazilian population, with miscegenation among various ethnic groups, mainly Caucasoid and African, allowing the occurrence of differences in prevalence among different regions of the country ${ }^{35}$.

According to the literature, analyses of the GJB2 gene in patients with hearing impairment frequently demonstrate heterozygosis in about $10 \%$ to $42 \%$ of cases, in spite of the fact that most of the mutations are recessive $e^{23,36,37}$. In this study, we found a $12.1 \%$ frequency of heterozygous index cases, a result that agrees with the literature $23,36,37$.

According to the audiometric results, in the present study the hearing loss was profound in $41.5 \%$ of patients, severe in $39.0 \%$, and moderate in $19.5 \%$, with a predominance of the high frequencies $(4000-8000 \mathrm{~Hz})$. In patients who were homozygous or heterozygous for $35 \mathrm{delG}$, the moderate-severe degrees of hearing loss were predominant, a pattern that is in agreement with the literature $\mathrm{e}^{17,38,39}$. Patients who are homozygous for 35 delG display a large variability in the degrees of hearing loss. Most of the autosomal recessive impairments are phenotypically rather consistent, even among sibs, a feature that is not observed for the GJB2-35del gene, mainly in heterozygous cases. This suggests the possibility of other factors modulating the expression of the mutant gene 40 . An intriguing possibility is that there may be a second conexin gene sharing functions with the GJB2 gene. It is conceivable that a second conexin protein might act as a substitute under certain conditions. Maybe there are modifier genes at other locations or environmental influences which activate or inactivate the promoter regions of the gene. As protein 
Cx26 is involved in the ion homeostasis of the inner ear, some of these patients may be capable of hearing, for they present a moderate hearing loss, suggesting the existence of alternative or compensatory homeostatic mechanisms. Alterations in protein Cx26 can adversely affect the development of the hearing system, resulting in variations of the degree of hearing loss or assymmetry ${ }^{38}$. Environmental influences, such as noises and ototoxic drugs, can be additive or synergists to the defects caused by mutations in the GJB2 gene, thus increasing the hearing loss ${ }^{17,38,41}$.

The clinical evaluations of patients in this study do not suggest that environmental causes are the main factors, considering that an autosomal recessive transmission pattern was identified in cases with the 35 delG mutation. Moreover, upon audiometric testing, these nine patients presented non-progressive audiometric findings, similar to those of patients described in the literature ${ }^{23,42-44}$ diagnosed with hearing impairment caused by mutation in the GJB2 gene. This confirms that the gene is involved in the etiology of the hearing loss of patients of this study with a phenotypic expression similar to that described in the literature ${ }^{23,42-44}$. In approximately one third of the cases of hearing impairment due to mutations in the GJB2 gene, an audiometric pattern of progressive hearing loss is found, as opposed to the two thirds of cases with the typical nonprogressive pattern. This means that a child with moderate hearing loss may progress to profound, and the therapies for these two kinds of degrees of hearing loss may be different. Families with a child with moderate-severe or profound hearing loss can be benefited by an analysis of the $\mathrm{GJB} 2^{38}$ gene.

The 35 delG mutation is easy to detect and the test is viable. However, since a great part of the patients with the 35delG mutation are homozygous, broader analyses of the GJB2 gene will be necessary in a high proportion of cases, in order to distinguish the common heterozygous carriers (healthy carriers) from the heterozygous patients with DFNB1. These broader analyses and investigations [including analyses of the entire coding region, the promoter region, the non-coding region of the gene and analyses of the Delta (GJB6-D13S1830) mutation], as performed in the present study, should be oriented by the clinical characteristics of DFNB1 ${ }^{43,45}$.

According to the literature, molecular tests associated to audiometric data can predict that a significant number of patients with the $35 \mathrm{del} G$ mutation will present a moderate-severe hearing loss and others are expected to present profound hearing loss ${ }^{29,44,46}$, as found in this study. Thus, in spite of the small casuistic, the audiometric pattern was concordant with the literature, enabling us to establish a genotype-phenotype correlation in the ten patients of the sample (9 index cases and 1 affected relative), i.e., the patients with the $35 \mathrm{del} G$ mutation presented a moderate-severe to profound, non-progressive hearing loss. A multicenter study is however necessary to verify the true phenotypic expression related to the $35 \mathrm{del}$ m mutation in the Brazilian population. Knowledge of the genotype will enable physicians, speech therapists, educators, helped by clinical geneticists, to provide more adequate counseling to parents by evaluating the risk of a future child having a similar hearing impairment. Children diagnosed before six months of age and submitted to a successful treatment with amplification will have a much greater chance of normally developing speech and language.

\section{REFERENCES}

1. Morton NE. Genetic epidemiology of hearing impairment. Ann N Y Acad Sci 1991;630:16-31.

2. Mustafa T, Arnos KS, Pandya A. Advances in hereditary deafness. Lancet 2001;358:1082-90.

3. Skvorak Giersch AB, Morton CC. Genetic causes of nonsyndromic hearing loss. Curr Opin Pediatr 1999;11(6):551-7.

4. Petit C. Genes responsible for human hereditary deafness: symphony of a thousand. Nature Genet 1996;14:385-91.

5. Van Camp G, Willems PJ, Smith RJH. Nonsyndromic hearing impairment: unparalleled heterogeneity. Am J Hum Genet 1997;60:75864.

6. Kelsell DP, Dunlop J, Stevens HP, Lench NJ, Liang, JN, Parry G, Mueller, RF, Leigh IM. Connexin 26 mutations in hereditary nonsyndromic sensorineural deafness. Nature 1997;387:80-3.

7. Kelley PM, Harris DJ, Comer BC, Askew JW, Fowler T, Smith SD, Kimberling WJ. Novel mutations in the connexin 26 gene (GJB2) that cause autossomal recessive (DFNB1) hearing loss. Am J Hum Genet 1998;62:792-9.

8. Scott DA, Kraft ML, Carmi R, Ramesh A, Elbedour K, Yari Y, Srisailapathy CRS, et al. Identification of mutation on the connexin 26 gene that cause autossomal recessive nonsyndromic hearing loss. Hum Mutat 1998;11:387-94.

9. Gabriel H, Kupsch P, Sudendey Jr, Winterhager E, Jahnke K, et al. Mutations in the connexin 26/GJB2 gene are the most common event in non-syndromic hearing loss among the German population. Hum Mutat 2001;17:521-2.

10. Van Camp G, Smith RJH. Na Hereditary Hearing Loss Homepage [Site na Internet]. Disponível em: http://webhost.ua.ac.be/hhh/. Acessado em 2006.

11. Zelante L, Gasparini P, Estivill X, Melchionda S, D’Agruma L, Govea N, Mila M, Della Monica M, et al. Connexin 26 mutations associated with the most common form of non-syndromic neurosensory autossomal recessive deafness (DFNB1) in Mediterraneans. Hum Molec Genet 1997;6:1605-9.

12. Estivill X, Fortina P, Surrey S, Rabionet R, Melchionda S, D'Agruma L, Mansfield E, Rappaport E, et al. Connexin 26 mutations in sporadic and inherited sensorineural deafness. Lancet 1998;351:394-8.

13. Antoniadi T, Gronskov K, Sand A, Pampanos A, Brondum-Nielsen K, Petersen MB. Mutation analysis of the GJB2 (connexin 26) gene by DGGE in greek patients with sensorineural deafness. Hum Mutat 2000;16:7-12.

14. Oliveira CA, Maciel-Guerra AT, Sartorato EL. Deafness resulting from mutations in the GJB2 (connexin 26) gene on Brazilian patients. Clin Genet 2002;61:354-8.

15. Kammen-Jolly K, Ichiki H, Scholtz AW, Gsenger M, Kreczy A, SchrottFischer A. Connexin 26 in human fetal development of the inner ear. Hear Res 2001;160(1-2):15-21.

16. Denoyelle F, Marlin S, Weil D, Moatti L, Chauvin P, Garabedian EN, Petit C. Clinical features of the prevalent form of childhood deafness, DFNB1, due to a connexin 26 gene defect: implications for genetic counselling. Lancet 1999;17(9161):1298-303.

17. Cryns K, Orzan E, Murgia A, Huygen PLM, Moreno F, del Castilo 
I, et al. A genotype-phenotype correlation for GJB2 (connexin 26) deafness). J Med Genet 2004;41:147-54.

18. World Health Organization. Report of the informal working group on prevention of deafness and hearing impairment programme planning. Geneva: WHO, 1991. 22p

19. Antoniadi T, Gronskov K, Sand A, Pampanos A, Brondum-Nielsen K, Petersen MB. Mutation analysis of the GJB2 (connexin 26) gene by DGGE in Greek patients with sensorineural deafness. Hum Mutat 2000;16:7-12.

20. del Castillo I, Villamar M, Moreno-Pelayo MA, del Castillo FJ, Alvarez A, Telleria $\mathrm{D}$, et al. A deletion involving the connexin 30 gene in nonsyndromic hearing impairment. N Engl J Med 2002;346:243-9.

21. Kelley PM, Harris DJ, Comer BC, Askew JW, Fowler T, Smith SD, Kimberling WJ. Novel mutations in the connexin 26 gene (GJB2) that cause autossomal recessive (DFNB1) hearing loss. Am J Hum Genet 1998;62:792-9.

22. Sobe T, Vreugde S, Shahin H, Berlin M, Davis N, et al. The prevalence and expression of inherited connexin 26 mutations associated with non-syndromic hearing loss in the Israeli population. Hum Genet 2000;106:50-7.

23. Wilcox SA, Saunders K, Osborn AH, Arnold A, Wunderlich J, et al. High frequency hearing loss correlated with mutations in the GJB2 gene. Hum Genet 2000;106:399-405.

24. del Castillo I, Villamar M, Moreno-Pelayo MA, del Castillo FJ, Alvarez A, Telleria $\mathrm{D}$, et al. A deletion involving the connexin 30 gene in nonsyndromic hearing impairment. N Engl J Med 2002;346:243-9.

25. Frei K, Szuhai K, Lucas T, Weipoltshammer K, Schofer C, Ramsebner $\mathrm{R}$, et al. Connexin 26 mutations in cases of sensorineural deafness in eastern Austria. Eur J Hum Genet 2002;10:427-32.

26. Pampanos A, Economides J, Iliadou V, Neou P, Leotsakos P, Voyiatzis, et al. Prevalence of GJB2 mutations in prelingual deafness in the Greek population. Int J Pediatr Otorhinolaryngol 2002;65:101-8.

27. Gasparini P, Estivill X, Volpini V, Totaro A, Castellvi-Bel S, et al. Linkage of DFNB1 to non-syndromic neurosensory autosomal-recessive deafness in Mediterranean families. Eur J Hum Genet 1997;5:83-8

28. Estivill X, Fortina P, Surrey S, Rabionet R, Melchionda S, D'Agruma L, Mansfield E, Rappaport E, et al. Connexin 26 mutations in sporadic and inherited sensorineural deafness. Lancet 1998;351:394-8.

29. Kenna MA, Wu B-L, Cotanche DA, Korf BR, Rehm HL. Connexin 26 studies in patientes with sensorineural hearing loss. Arch Otolaryngol Head Neck Surg 2001;127:1037-42.

30. Simsek M, Al-Wardy N, Al-Khayat A, Shanmugakonar M, Al-Bulushi $\mathrm{T}$, Al-Khabory $\mathrm{M}$, et al. Absence of deafness associated connexin 26 (GJB2) gene mutations in the Omani population. Hum Mutat 2001;18:545-6.

31. Nance WE. The genetics of deafness. Ment Retard Disabil Res Rev 2003;9:109-19.

32. del Castillo I, Moreno-Pelayo MA, del Castillo FJ, Brownstein Z, Marlin S, Adina Q, et al. Prevalence and Evolutionary Origins of the del(GJB6-D13S1830) Mutation in the DFNB1 Locus in Hearing Impaired Subjects: a Multicenter Study. Am J Hum Genet 2003;73:1452-8.
33. Piatto VB, Oliveira CA, Alexandrino F, Pimpinati CJ, Sartorato EL Perspectivas para triagem auditiva genética: rastreamento da mutação 35delG em neonatos. J Pediatr 2005;81:139-42.

34. Sartorato EL, Gottardi E, Oliveira CA, Magna LA, Annichio-Bizzacchi JM, Seixas CA, Maciel-Guerra AT. Determination of the frequency of the 35delG in Brazilian neonates. Clin Genet 2000;58:339-40.

35. Oliveira CA, Alexandrino F, Abe-Sandes K, Silva Jr WA, Maciel-Guerra AT, Magna LA, Sartorato EL. Frequency of $35 \mathrm{delG}$ in the GJB2 gene in samples of Caucasians, Asians and African Brazilians. Hum Biol 2004;76:313-6

36. Pandya A, Arnos KS, Xia XJ, Welch KO, Blanton SH, Friedman TB, et al. Frequency and distribution of GJB2 (connexin 26) and GJB6 (connexin 30) mutations in a large North American repository of deaf probands. Genet Med 2003;5:295-303.

37. Stevenson VA, Ito M, Milunsky JM. Connexin-30 deletion analysis in connexin-26 heterozygotes. Genet Test 2003;7:151-4

38. Cohn ES, Kelley PM, Fowler TW, Gorga MP, Lefkowitz, et al. Clinical studies of families with hearing loss attributable to mutations in the connexin 26 gene (GJB2/DFNB1). Pediatrics 1999;103:546-50.

39. Murgia A, Orzan E, Polli R, Martella M, Vinazi C, Leonardi E, Arslan E, Zacchello F. Cx26 deafness: mutation analysis and clinical variability. J Med Genet 1999:36:829-32.

40. Marlin S, Garabedian E-N, Roger G, Moatti L, Matha N, Lewin P, Petit C, Denoyelle F. Connexin 26 gene mutations in congenitally deaf children. Arch Otolaryngol Head Neck Surg 2001;127:927-33.

41. Rabionet R, Zelante L, Lopez-Bigas N, DAgruma L, Melchionda S, Restagno $G$, et al. Molecular basis of childhood deafness resulting from mutations in the GJB2 (connexin 26) gene. Hum Genet 2000;106:404.

42. Cohn ES, Kelley PM. Clinical phenotype and mutations in connexin 26 (DFNB1/GJB2), the most commom cause of childhood hearing loss. Am J Med Genet 1999;89:130-6.

43. Denoyelle F, Marlin S, Weil D, Moatti L, Chauvin P, Garabedian EN, Petit C. Clinical features of the prevalent form of childhood deafness, DFNB1, due to a connexin 26 gene defect: implications for genetic counselling. Lancet 1999;17:1298-303.

44. Engel-Yeger B, Zaaroura S, Zlotogora J, Shalev S, Hujeirat Y, Carrasquilo M, Barges S, Pratt $\mathrm{H}$. The effects of a connexin 26 mutation - 35delG - an oto-acoustic emissions and brainstem evoked potentials homozygotes and carriers. Hear Res 2002;163:93-100.

45. Mustapha M, Salem N, Delague V, Chouery E, Ghassibeh M, Rai M, Loiselet J, Petit C, Megarbane A. Autosomal recessive non-syndromic hearing loss in the Libanese population: prevalence of the 30delG mutation and report of two novel mutations in the connexin 26 (GJB2) gene. J Med Genet 2001;38:e36.

46. Yoshinaga-Itano C, Sedey AL, Coulter DK, Mehl AL. Language of early-and later-identified children with hearing loss. Pediatrics 1998;102:1161-71. 